\title{
Commentary: Archaeology as Travel and Tourism
}

\author{
Matthew H. Johnson
}

Published online: 28 April 2011

(C) Springer Science+Business Media, LLC 2011

In their introduction to this special issue of the $I J H A$, Maria O'Donovan and Lynda Carroll speak of the original session at the York 2005 SHA meetings that formed the springboard for this volume, and of their very sensible decision to limit its scope to nineteenth- and twentieth-century tourist sites in the United States. In this brief commentary, I want nevertheless to place these papers in a wider context, in terms of space, time, and theoretical perspective.

In particular, I want to draw out what we have learnt about the close relationship between the practice of archaeology and the practice of tourism. I want to suggest that the archaeological gaze and the tourist gaze are not so very far apart; that archaeologists would do well to be more reflexive about the relationship of their work to the practices of tourism; that the line drawn between archaeological and tourist practice is quite a fine one.

Such an observation should not surprise us. After all, both archaeology and tourism are artifacts of modernity (Thomas 2004; Urry 2002). LouAnn Wurst and Stacy Lynn Camp rightly stress how tourist practices push the labor relations that sustain them into the background, or remove them from sight entirely. Something similar, of course, happens to the labor of diggers, finds assistants, and so on in the archaeological process. Troy Lovata reminds us that the relationship between scholars and tourists has never been one-directional, and it has rarely been a distant one either.

I think the point is worth stressing, however, because in much of the academic literature on tourism there is more than a hint of elitism. The "tourist gaze" is seen as being commodified, packaged, limited; even as the concept of "authenticity" is critiqued (Urry 2002, pp. 122-123), so, it is implied, the tourist experience is somehow inauthentic, at least when held up against dispassionate academic knowledge. Archaeologists themselves, of course, go on holiday from time to time, and it is not always clear when tourist activity begins and academic "work" ends;

M. H. Johnson $(\bowtie)$

School of Humanities, University of Southampton, Avenue Campus, Highfield,

Southampton SO17 1BF, UK

e-mail: m.h.johnson@soton.ac.uk 
was a Chicago professor, wandering around the exhibits organized by Franz Boas at the 1893 World's Fair, working or being a tourist?

This bordering terrain, even shared terrain, can be demonstrated by a brief tour (tourist trip?) through the history of archaeology. Arguably, the first archaeological traveler in the English-speaking world was John Leland. In the opening decades of the sixteenth century, Leland set himself the task of traveling from one corner of England and Wales to the other. Leland armed himself with official travel documents - his appointment as King's Antiquary in 1533 was the result of his own lobbying - and documents signed by Henry VIII secured him official sanction for his enquiries. Leland traveled from monastery to castle to town, and he noted down what he saw in what to the modern reader seems a random and unsystematic jumble. Leland planned to bring order and method to his observations by writing a book entitled De Antiquitate Britannia. However, the task of bringing order to his observations must have been too much for Leland, because the poor man went mad before he was able to complete the task (Parry 2007, p. 34).

Leland wanted to see things, and he wrote down what he saw. A central and guiding element of the archaeological process, and the tourist gaze, is the desire to see things for oneself rather than trust to what one reads in books (the science fiction writer Asimov (1995, p. 75) wrote of a fictional future in which lack of such curiosity was a key diagnostic trait of cultural decline and stagnation). It is arguable that such a desire to go out and look sprang, in part, from the guiding principles of the "scientific revolution" of the seventeenth century, in which many natural philosophers sought to actively discard the texts of the Ancients and replace such authorities with trained empirical observation. Such a desire, of course, immediately raised issues of what counted as trained empirical observation and in particular whose word was to be trusted, for example, the word of a gentleman (Shapin 1996, pp. 85-96). The desire to observe, and conversely a distrust of accepted knowledge, requires a radical separation between subject and object, in order to create the conditions in which the object can be observed. It also required a radical separation between the (unreliable) world of everyday opinion and the (reliable) world of the educated gentleman.

Such an argument is an oversimplification, but it is certainly true that the origins of archaeology as a discipline were bound up with two particular forms of travel and nascent tourism. The first was the Grand Tour. Seventeenth- and eighteenth-century aristocratic men, and occasionally aristocratic women, finished their education with travel to the great cities of Europe and the Mediterranean, to see the great works of art and archaeological monuments, particularly those of the classical past. Young men were accompanied by a tutor, to explain to them the cultural value of what they saw, and where they could afford it, these men bought and acquired art items - souvenirs - which they brought back to their country houses (Schnapp 1993).

The second form of travel was more local. Men of the gentry classes, financially unable to send their sons on the Grand Tour, interested themselves in local antiquities-burial mounds, local medieval churches, Roman sites and monuments, earthworks of all kinds. If the Grand Tour reflected a sensibility of classical origins, this local interest was tied up with an emergent national consciousness. Thomas Jefferson's famous excavations of Native American 
burial mounds stand at the genesis of North American archaeology - but they are descended from the centuries-old practice of northern European gentlemen digging into whatever they fancied in the local landscape (or more accurately, ordering their laborers to dig).

Archaeology has traditionally had a very strong association with leisure activity. There is an important distinction to be made between leisure and pleasure; cultural anthropologists insist that leisure is more disciplined activity, manifesting itself in, for example, organized sport rather than undisciplined hedonism, or in organized fox-hunting rather than solitary hunting (Kohn and Coleman 2007, p. 3).

There has traditionally been a huge middle ground between the undisciplined activities of some tourists, travelers, and treasure hunters, on the one hand, and the professional institutions of the academy and of heritage organizations on the other. In the past, archaeology derived much of its strength and appeal as a discipline from this middle ground of leisure activity. For the great landscape historian W.G. Hoskins, "[The author's] hobby is exploring England on foot, a pursuit of inexhaustible interest in which he reckons to make at least one major 'discovery' each week" (Hoskins 1954, back flyleaf). The dedication of one of the key classic works of early field archaeology reveals that it is written by an amateur, "a man with a hobby"; archaeology is here both a leisure pursuit involving "many pleasant expeditions" and also a demanding, physically draining pursuit that tests the patience and endurance of his companions (Williams-Freeman 1915, p. vii):

TO

ALL THOSE FRIENDS

(OR TO THOSE WHO STILL REMAIN THE SAME)

WHOM I HAVE PRESSED INTO THE SERVICE OF VISITING THESE CAMPS WHO HAVE CLAMBERED UP THE HEIGHTS AND SLID INTO THE DEPTHS WHO HAVE STRUGGLED WITH THE TAPE AND SUFFERED UNDER THE RODS WHO HAVE OFTEN ASSUMED THE GAIT AND SOMETIMES THE DIET OF THE SERPENT

AND ABOVE ALL

WHO HAVE BORNE IN SILENCE

(MORE OR LESS)

THE INFLICTIONS OF A MAN WITH A HOBBY

I DEDICATE THIS BOOK

IN MEMORY OF

(TO ME)

MANY PLEASANT EXPEDITIONS

The archaeologist and pioneer of air photography OGS Crawford was quite explicit in making a link between archaeology, on the one hand, and leisure and nationalism on the other. He insisted that the whole method of what he called field archaeology was "a modern, and primarily a British invention" and went on to suggest that field archaeology as he had defined it "is an essentially English form of sport," in part, he asserted, due to the presence of "persons of means, leisure and intelligence" living in the country (Crawford 1953, pp. 52-53). The examples I have 
cited are (with the exception of Jefferson) British, and it could be argued that Crawford was on to something, in that amateur activity in the British landscape was, and is, facilitated by both its small scale (you can do meaningful fieldwork on a Saturday afternoon, an hour's drive from the center of town) and by the early presence from the Industrial Revolution of a self-confident middle class (one that quickly organized itself into "field clubs" and amateur societies; Williams-Freeman was a key early figure in the Hampshire Field Club).

Histories of archaeology like to sanitize the early activities of early antiquarians by seeing them in terms of evolutionary progress, seeing early efforts as often crude and unsystematic, like Leland held back in their earlier stages by their lack of a clear system and observational language. Field archaeology, then, becomes a narrative of "progress," starting with the jumbled observations of Leland, moving through the "pioneering" work of figures like Jefferson and Hoskins, and ending with the order and method of the modern site report. It is a familiar point that one of the problematic features of such progressive narratives is their assumption of a past lying out there to be "discovered"- - just as, for the tourist, there is an authentic world of Nature lying out there waiting to be taken in by the tourist gaze. According to Raymond Williams (1976, p. 184) nature is "perhaps the most complex word in the language." If there is one message to be taken away from the papers in this volume, it is that travel, tourism, to archaeology are never innocent experiences; they must always be seen in their economic, social, cultural, and ideological context.

Tourist locations, whether "heritage sites" or "natural" landscapes, pull off an impressive triple ideological trick. First, they persuade citizens that they have a stake in the landscape, without those ordinary citizens actually owning it. Monuments and places become part of a national heritage - a venerable repository of memory and identity - from the Acropolis in Athens, to the Grand Canyon, to Jefferson's home at Monticello, to Winston Churchill's home at Chartwell, to the Four Corners. Even where such places are federally or state-owned, they are the locus of interests, and are controlled by bodies, that are not always publicly accountable or open to a democratic evaluation and participation; nevertheless, such monuments are held to be part of a local or national heritage that is in some indefinable, ineffable sense owned by everyone. To describe such places as ideological in this way is not to make the claim that in "reality" they have nothing to offer the public or that they are in some way fraudulent; the work of Leone and Silberman (1995) shows how such places can be opened up in a vision of an "invisible America," and it was the leftist Woody Guthrie who insisted on this land being made for you and me. The experience of Spring Mill State Park, as described by Melody Pope and April and Sheree Sievert, shows that the role of the historic site as tourist attraction is more complex than a simple or vulgar piece of ideology. In their subtle and nuanced study, they show how Spring Mill can be seen as "inauthentic" by visitors. Visitors to Spring Mill project their own impressions and interpretations on to the site despite the best intentions of the authorities.

Second, tourist sites persuade the tourist that their view is "authentic," rather than constructed. To be authentic, travel and tourism have to be constructed as solitary or innocent experiences, unmediated encounters with Nature (or with "the past"). Behind the pleasurable experiences and lofty gaze of the traveler and tourist lie a whole suite of labor relations and social realities. In extreme cases, as documented 
by Troy Lovata at Manitou Springs, the "archaeology" is even physically moved to be accessible to the tourists; his discussion reminded me of the experience of visiting Knossos in Crete. Though Knossos has not been moved, tourists experience the concrete elements of Sir Arthur Evans' "restoration" of the site and imbibe its modernist values in a way that is arguably as far removed from an authentic original as anything at Manitou Springs (Gere 2009). In the case of the Chicago World's Fair discussed by Rebecca Graff, different elements of the archaeological world are presented as part of one panoramic sweep, an exposition of human experience across the world distilled and presented in one metropolitan location. In the process of creating authenticity, the view is aestheticized-it becomes "local color." Stacey Lynn Camp notes how Los Angeles' ethnic diversity is masked by the tourist trail, but such diversity also becomes an object of aesthetic contemplation by the tourist, and in the process it is essentialized and anaesthetized.

Third, sites are constructed in such a way as to silence or mask labor relations. The engagement of tourists in consumption and leisure always has a flip-side - in the organization and labor relations of the tourist industry. As Stacey Lynn Camp notes, tourism is the largest industry on earth, and yet its labor relations and material traces are characteristically hidden or otherwise denied. We see this double nature of tourism most clearly in the papers by Maria O'Donovan and Lou-Ann Wurst. The Borscht Belt and Niagara Falls are places not simply of great "natural beauty," passive recipients of the tourist gaze. Rather, both places are brought into being, rendered accessible through the development of infrastructure, travel, transport, and hotels, the presence and activities of an army of "service" workers and the accommodation and other facilities needed. And archaeological places are brought into being, in part, through the labor of archaeologists. This is sometimes literally true; the tourist site of the Athenian Acropolis was created by intensive archaeological excavations in the nineteenth century-scraping of successive layers of Ottoman, medieval, Byzantine, and Roman occupation, and removing great walls and towers - to leave the Parthenon and its associated buildings in a state held to approximate to fifth century CE Athens (Yalouri 2001).

Many artifacts of the archaeology of travel and tourism do ideological work along all three of these axes. The railroad, for example, links up different tourist sites and places, and its installations and landscapes themselves become objects of "heritage" (Grand Central Station, the railroad landscapes of the American West). The view from the railway carriage becomes an iconic representation of the countryside- from views of the English Downs to the sweep of the Great Plains. And the railroad itself becomes a Romantic object, separated from the labors that produced it-Uzi Baram shows us how the railroad is much more than simply a line of travel and communication; it has a whole suite of associated activities and installations alongside it.

I have described the triple ideological function of sites and landscapes in very topdown terms. What an informed archaeology does, in response to this situation, is to excavate in two senses. It uncovers the material traces, and in the same action uncovers forgotten or ideologically silenced traces of labor relations, both past and present. It does so using material that, at first sight, is not particularly promising. One of the exciting things about several of these papers is the way that they deploy "raw data" from the prosaic demands of CRM, contract archaeology, "archaeological 
mitigation" (Graff), and related preservation issues. These papers use mundane archaeological material derived in part from small-scale interventions; however, the conclusions reached are anything but mundane-it is harnessed in the service of wider anthropological questions; we move from the grubbing of the Ditch Witch to multivocality in a seamless and confident manner.

For Rebecca Graff, the 1893 Chicago World's Fair acts as a sign pointing in several different, though related, directions. The reference to Beck et al. (2007) is apt, because the Fair becomes a key constitutive event in the constitution of "tourism" at the end of the nineteenth century in the United States. It is also a key reference-point in the development of a Boasian anthropology, and in the urban development of Chicago itself. For Graff, the 1893 Fair creates, as well as caters for, a particular kind of tourist perception; Graff makes a strong link between the materiality of the Fair itself, and the need for an enhanced archaeological sensibility in the Chicago of the present.

What these papers have in common is first that they rightly insist that travel and tourism should be taken seriously by archaeologists, just as Kohn and Coleman (2007) insist that leisure should be taken seriously by cultural anthropologists. I have argued in this brief discussion that taking travel and tourism seriously involves an evaluation of the historical and intellectual links between archaeology and tourism, and critical reflection on the current place of archaeology within the heritage work that goes on at tourist sites. This excellent set of papers marks a beginning in opening up such a process (the work of Holtorf 2007 marks another beginning). The deepening of this reflection will not only enhance our understanding of the archaeology of travel and tourism, but reflect back and lead to more profound reflection on the practices and desires of the discipline of archaeology itself.

\section{References}

Asimov, I. (1995). Foundation, Harper Collins, London.

Beck, R., Bolender, D., Brown, J. A., and Earle, T. K. (2007). Eventful archaeology: The space and place of structural transformation. Current Anthropology 48: 833-860.

Crawford, O. G. S. (1953). Archaeology in the field, Phoenix House, London.

Gere, K. (2009). Knossos and the prophets of modernism, University of Chicago Press, Chicago.

Holtorf, C. (2007). Archaeology is a brand! The meaning of archaeology in contemporary popular culture, Left Coast, Walnut Creek.

Hoskins, W. G. (1954). Devon, Collins, London.

Kohn, T., and Coleman, S. M. (eds.) (2007). The discipline of leisure: Embodying cultures of "recreation", Berghahn, New York.

Leone, M., and Silberman, N. (1995). Invisible America: Unearthing our hidden history, Holt, New York.

Parry, G. (2007). The discovery of Britain. In Starkey, D. (ed.), Making history: Antiquaries in Britain 1707-2007, Royal Academy of Arts, London, pp. 15-50.

Schnapp, A. (1993). The discovery of the past, Editions Carree, Paris.

Shapin, S. (1996). The scientific revolution, University of Chicago Press, Chicago.

Thomas, J. (2004). Archaeology and modernity, Routledge, London.

Urry, J. (2002). The tourist gaze, 2nd ed, Sage, London.

Williams, R. (1976). Keywords: A vocabulary of culture and society, Fontana, London.

Williams-Freeman, J. P. (1915). An introduction to field archaeology as illustrated by Hampshire, Macmillan, London.

Yalouri, E. (2001). The acropolis: Global fame, local claim, Berg, Oxford. 